\title{
Perianal Abscess
}

National Cancer Institute

\section{Source}

National Cancer Institute. Perianal Abscess. NCI Thesaurus. Code C99092.

An abscess that develops in the soft tissues surrounding the anal canal. Causes include bacterial and fung al infections, malignancies that involve the perianal region, and Crohn disease. 